
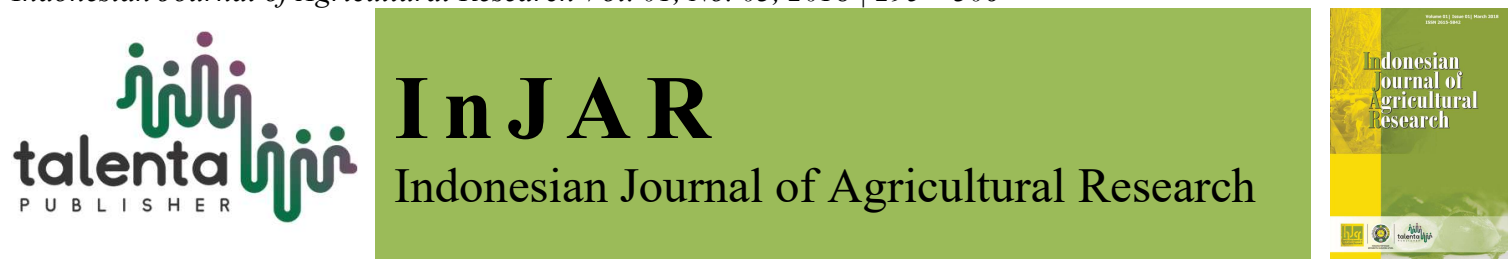

\title{
The Growth and Yield of Rice (Oryza sativa L.) with Organic and Inorganic Fertilizer Application by Cellulolytic Microbes in Peat
}

\author{
Atrisina Allamah, Hapsoh, Wawan, and Isna Rahma Dini \\ Agrotechnology Department, Agriculture Faculty, Universitas Riau
}

\begin{abstract}
Limitations of productive land causing agricultural extension leads on marginal land. Peatlands are one type of land including the criteria for marginal land. Destruction of peatland ecosystems arising from land management and the selection of one commodity which is not in accordance with the characteristics of peatland. Damage criteria peat in government regulations to function cultivation is more than $0,4 \mathrm{~m}$ below the peat surface. One alternative for the agricultural development of peatlands associated with groundwater levels $\leq 0,4 \mathrm{~m}$ to do with the development of food crops, especially rice crops. This is because the root system of the rice crop is only about $40-50 \mathrm{~cm}$ categorized shallow roots, thus suitable for development on peatland shallow. This study aims to determine the response growth and yield of rice plants with organic and inorganic fertilizer application by microbial cellulolytic on peat soil. The experimental was conducted from November 2017 to January 2018 in Laboratory of Soil Science and Plant Laboratory, Faculty of Agriculture at Universitas of Riau. The research was conducted using a completely randomized design (CRD), which consists of 7 treatments and 4 replicates so on May 28 experimental units. As for the treatment Control, $50 \%$ inorganic fertilizer, $100 \%$ inorganic fertilizer, 80 grams of composted rice straw, 160 grams of litter rice straw $+160 \mathrm{ml}$ consortium of microbes, 80 grams of composted rice straw $+50 \%$ inorganic fertilizer, 160 grams of rice straw litter + $160 \mathrm{ml}$ of microbial consortium selulitik $+50 \%$ inorganic fertilizer. The results showed that addition of $160 \mathrm{~g}$ of rice straw litter $+160 \mathrm{ml}$ of microbial $+50 \%$ inorganic fertilizer consortium was the best treatment by producing tillers reaching 54,87 tillers, the number of grain per panicle reached 130.57 grains with crop grain weight reaching 57.27 grams, with a percentage of empty the lowest is $3.62 \%$.
\end{abstract}

Keywords: fertilizer, inorganic, microbial cellulolytic, organic, Oryza sativa L, peat

Received 27 October 2018 | Revised 24 January 2019] | Accepted 01 February 2019

\section{Introduction}

Limitations of productive land causing agricultural extension leads to marginal lands. Peatlands are one type of land included in the criteria of marginal land. Riau is a province that has a vast peatland and enough potential to be developed as agricultural land. Destruction of peatland ecosystems arising from land management and the selection of one commodity which is not in accordance with the characteristics of peatland.

\footnotetext{
*Corresponding author at: Magister of Agriculture Sciences Department, Agriculture Faculty, University Riau, Kampus Bina Widya KM. 12,5 Panam Pekanbaru 28293, Indonesia

E-mail address: atrisinaallamah@gmail.com
} 
The Indonesian government has issued Government Regulation No. 71 of 2014 and No. 572016 on procedures for groundwater level measurement arrangement dititik peat ecosystem, especially the obligation maintain groundwater levels at the rate of $40 \mathrm{~cm}$ [1]. Damage criteria peat in government regulations to function cultivation is more than $0,4 \mathrm{~m}$ below the surface of the peat [2].

One alternative for the agricultural development of peatlands associated with groundwater levels $\leq 0,4 \mathrm{~m}$ to do with the development of food crops, especially rice crops. This is because the root system of the rice crop is only about $40-50 \mathrm{~cm}$ categorized shallow roots, thus suitable for development on peatland shallow. According to the Policy Synthesis Team, type of peat is very shallow $(<50 \mathrm{~cm})$ can be used for wetland. Paddy rice can be cultivated on peatlands with a shallow peat layer thickness at depth $(0,5-1,0 \mathrm{~m})$ [3].

Efforts will be undertaken to improve the productivity of nutrients and peat land, necessary improvements to the macro nutrient in peat, such as $\mathrm{N}, \mathrm{P}$, and $\mathrm{K}$ which is a major nutrient for plant growth. Increased availability of macro nutrients like N, P, and K need to be considered regarding the availability and the need for fertilizers to crops. Rosmimi and Septiadi research results show that administration of each dose of $\mathrm{N}, \mathrm{P}$ and $\mathrm{K}$ on rice plants in peat medium ranging from $1,1,5$ and 2 times the recommended dosage of (Urea $0.875 \mathrm{~g} /$ pot, TSP $0,375 \mathrm{~g} /$ pot and $\mathrm{KCl}$ $0.375 \mathrm{~g} /$ pot) produces $\mathrm{N}$ uptake by the roots and canopy are consecutive respectively increased by $29.87 \%$ and $299.08 \%$, P uptake by roots and canopy increased by $13.89 \%$ and 239.52 as well and $\mathrm{K}$ nutrient uptake by roots and canopy increased by $16.97 \%$ and $153 \%$ [4].

Attempts to combine the use of organic and inorganic fertilizers were applied to the rice crop will provide an opportunity to increase production in a sustainable manner. Organic material is good for peat is an organic material that has the capability of providing a high base saturation, can increase the $\mathrm{pH}$ level in real time, is able to improve the soil structure, having a complete nutrient content, and is able to repel toxic compounds, especially acid organic acids [5]. According Ekawati said that the chemical composition of rice straw is: $36,65 \%$ cellulose, lignin $6.55 \%$, $0.3152 \%$ polyphenols, $41.30 \%$ organic $\mathrm{C}, 1 \% \mathrm{~N}, 0.33 \% \mathrm{~K}$, with a ratio of C/N 41.30 [6].

Efforts to accelerate the decomposition of rice straw by using decomposers can be cellulolytic bacteria. Cellulolytic bacteria is a bacteria that can produce cellulase enzymes for cellulose degrade be derivative compounds such as glucose, maltose and so on [7]. Selection of cellulolytic bacteria as a cellulose degrading microbes have a faster growth rate than the group of other microbes to produce enzymes [8].

Currently, studies and reports on the application of organic fertilizers and inorganic litter rice straw with the help of cellulolytic microbe has not been done. Therefore, it is necessary to conduct research related to the application of organic and inorganic fertilizers with application by cellulolytic microbes. The research aims to study the main effect of determine the use of organic 
and inorganic fertilizers with capable microbial technology. Increase productivity and yield of rice and nutrient content of $\mathrm{N}, \mathrm{P}$ and $\mathrm{K}$ in the research soil.

\section{Materials and Methods}

\subsection{Study Area and Materials}

This study was conducted on November 2017 to January 2018 at the Technical Services Unit Experimental Station, Faculty of Agriculture, Universitas of Riau. Analysis of soil and plants will be conducted at the Laboratorium for Soil and Plant Laboratory, Faculty of Agriculture, Universitas of Riau. This study was conducted experimentally using completely randomized design (CRD), which consists of 7 treatments and 4 replicates so there are 28 experimental units. As for the treatment P0: Control, P1: 50\% inorganic fertilizer, P2: 100\% inorganic fertilizer, P3: 80 grams of composted rice straw, P4: 160 grams of litter rice straw $+160 \mathrm{ml}$ consortium of microbes, P5: 80 grams of composted rice straw $+50 \%$ inorganic fertilizer, P6: 160 grams of rice straw litter $+160 \mathrm{ml}$ of microbial consortium selulitic $+50 \%$ inorganic fertilizer. The parameters were observed namely plant height, number of tillers, age out panicle, panicle length, panicle density, number of grains per panicle, the percentage of empty grain, grain weight per plant and chemical analysis of soil N, P, K peat after harvest.

\subsection{Data Analysis}

The data have been obtained from chemical analysis of the soil $(\mathrm{pH}, \mathrm{N}, \mathrm{P}$, and $\mathrm{K}$ ) were carried out in Laboratorium for Soil and Plant Laboratory, Faculty of Agriculture, Universitas of Riau, it was presented in table form. For the growth and yield of rice plants, the observed data of each treatment was statistically processed using the Fingerprint Variety, if the results of analysis of variance showed significant differences there will be a further test using test Duncan's Multiple Range Test (DMRT) at level 5\%.

\section{Results and Discussion}

\subsection{Chemical Properties of Peat}

Chemical properties of peat used for research before giving treatment are presented in Table 1. Table 1 showed that the peat in this study had a pH of 4.12 and included in the criteria very acid. Conditions were very acidic peat soil is caused by the accumulation of organic matter and soil in anaerobic environments, so a lot of formed organic acids (carboxylic and phenolic compounds). The reaction $\mathrm{pH}$ is a parameter that is controlled by the electronic properties of soil colloids. The level of acidity can affect the availability of nutrients in the soil [9].

The content of $\mathrm{N}$-total in peat soil that is classified as moderate by $0.43 \%$. The nitrogen in the peat soil is difficult available for plants in peat as it is used by the microorganisms in the decomposition of organic materials contained in the peat. Rajagukguk stated that the levels of 
total nitrogen peat soils are generally high but $\mathrm{N}$ will only be available after the drainage and mineralization, another case on peat soils in waterlogged conditions, nitrogen will be used for the decomposition of peat by microorganisms that are not available to plants [10].

The content of P-available peat soils very relatively high at $182.33 \mathrm{ppm}$. As for the content of K on peat soil as very low, amounting to $0.20 \mathrm{mg} / 100 \mathrm{~g}$. Low of $\mathrm{N}$ and $\mathrm{K}$ on peat soil suspected of peatland is the result of the accumulation of organic matter that has not decomposed completely and causing peat nutrient poor $\mathrm{N}$ and $\mathrm{K}$, and therefore nutrient $\mathrm{N}$ and $\mathrm{K}$ on peat soil is indispensable to changes in soil fertility [11].

Table 1. Chemical Properties of Peat Soil Before Application Treatment

\begin{tabular}{lccc}
\hline \multicolumn{1}{c}{ Soil Chemical Properties } & Unit & Value & Criteria \\
\hline soil pH & & 4.12 & very sour \\
Organic C (\%) & $\%$ & 28.72 & very high \\
N total (\%) & $\%$ & 0.43 & moderate \\
P potential (HCl 25\%) & g g-1 (ppm) & 50.96 & very high \\
K potential (HCl 25\%) & $100 \mathrm{mg} \mathrm{g}-1$ & 40.57 & moderate \\
Available P (P-Bray 1) & ppm & 182.33 & very high \\
Bases that can be exchanged & & & \\
K-dd & cmol (+) kg-1 & 0.20 & low \\
Ca-dd & cmol $(+) \mathrm{kg}-1$ & 0.65 & very low \\
Mg-dd & cmol (+) kg-1 & 0.11 & very low \\
Na-dd & cmol (+) kg-1 & 0.13 & low \\
base saturation & $\%$ & 3.01 & very low \\
Cation Exchange Capacity (CEC) & $\mathrm{cmol}(+) \mathrm{kg}-1$ & 36.16 & high \\
\hline
\end{tabular}

Note: The results of the analysis of soil science laboratory of the Faculty of Agriculture, University of Riau in 2018

\subsection{Plant Height}

Results of analysis of variance showed that the application of organic and inorganic fertilizers with microbial technology provides not significantly different on plant height 14, 12, and 28 days after planting (DAP) but significantly effect on plant height 35, 42, and 49 DAP. The growth responses of rice plants to organic fertilizers and inorganic seen starting at 35, 42, and 49 DAP. In the vegetative phase end of the treatment 160 grams of litter rice straw $+160 \mathrm{ml}$ consortium of microbes $+50 \%$ inorganic and general plant by application $100 \%$ organic, $50 \%$ inorganic and treatment of organic fertilizer has the same height, while the high response of plants to treatment (control) showed the average height of the plants was lower, $73 \mathrm{~cm}$ differ significantly with all treatments. This is caused by the availability of nutrients $\mathrm{N}, \mathrm{P}$, and $\mathrm{K}$ can be absorbed by the roots of plants used in the process of photosynthesis so as to improve the response of plant height. This is in line with research Yuwono, which states that the height of the plant affected by the availability of nutrients and the absorption of nutrients by plant roots, where roots play an important role for the roots to function as an absorber of nutrients and translocation of elements from the root to the stem, leaves, or fruits [12]. 
Table 2. Upland Rice Plant Application of Organic and Inorganic Fertilizers With Microbial Technology $(\mathrm{cm})$

\begin{tabular}{ccccccc}
\hline & \multicolumn{7}{c}{ Plant height $(\mathbf{c m})$} \\
\cline { 2 - 7 } Treatment & $\mathbf{1 4}$ & $\mathbf{2 1}$ & $\mathbf{2 8}$ & $\mathbf{3 5}$ & $\mathbf{4 2}$ & $\mathbf{4 9}$ \\
& DAP & DAP & DAP & DAP & DAP & DAP \\
\hline P0 & $13 \mathrm{a}$ & $16 \mathrm{a}$ & $21 \mathrm{a}$ & $33 \mathrm{c}$ & $44 \mathrm{c}$ & $57 \mathrm{e}$ \\
P1 & $13 \mathrm{a}$ & $16 \mathrm{a}$ & $25 \mathrm{a}$ & $35 \mathrm{bc}$ & $48 \mathrm{bc}$ & $63 \mathrm{~cd}$ \\
P2 & $13 \mathrm{a}$ & $16 \mathrm{a}$ & $29 \mathrm{a}$ & $41 \mathrm{a}$ & $53 \mathrm{a}$ & $70 \mathrm{a}$ \\
P3 & $13 \mathrm{a}$ & $16 \mathrm{a}$ & $23 \mathrm{a}$ & $33 \mathrm{c}$ & $45 \mathrm{c}$ & $60 \mathrm{de}$ \\
P4 & $13 \mathrm{a}$ & $16 \mathrm{a}$ & $23 \mathrm{a}$ & $33 \mathrm{c}$ & $45 \mathrm{c}$ & $64 \mathrm{bcd}$ \\
P5 & $13 \mathrm{a}$ & $16 \mathrm{a}$ & $23 \mathrm{a}$ & $36 \mathrm{bc}$ & $47 \mathrm{bc}$ & $66 \mathrm{abc}$ \\
P6 & $13 \mathrm{a}$ & $16 \mathrm{a}$ & $26 \mathrm{a}$ & $38 \mathrm{ab}$ & $51 \mathrm{ab}$ & $70 \mathrm{a}$ \\
\hline
\end{tabular}

Numbers followed by the same lowercase letters in each treatment was not significantly different according to Duncan's Multiple Range Test at 5\% level. P0 = Without treatment; $\mathrm{P} 1=50 \%$ inorganic fertilizer; $\mathrm{P} 2=100 \%$ inorganic fertilizer; $\mathrm{P} 3=80 \mathrm{~g}$ of rice straw compost; $\mathrm{P} 4=160 \mathrm{~g}$ rice straw litter $+160 \mathrm{ml}$ consortium of microbial $/$ plant; $\mathrm{P} 5=80 \mathrm{~g}$ of rice straw compost $+50 \%$ inorganic fertilizer; $\mathrm{P} 6=160 \mathrm{~g}$ rice straw litter $+160 \mathrm{ml}$ of microbial consortium $+50 \%$ inorganic fertilizer

\subsection{Number of Tillers, Age Out Panicle, Panicle Length and Panicle Density}

Results of analysis of variance showed that the application of organic and inorganic fertilizers with microbial technology provides significant effect on the number of tillers, age out panicle, panicle length and panicle density (Table 3). This is caused by inorganic and organic fertilizers and microbes in the medium of capable peat soil provide nutrients $\mathrm{N}, \mathrm{P}$, and $\mathrm{K}$ in a balanced state can be absorbed by the roots of plants and translocated to the stem and leaves so that it can increase plant growth. The addition of organic and inorganic fertilizers and microbial consortium greatly influences growth and yield potential. Giving microorganisms in the form of biological fertilizers (biofertilizer), such as non-symbiotic nitrogen fixation bacteria inoculants (Azotobacter sp. and Azospirillum sp.) and phosphate solvent bacteria (Bacillus megaterium and Bacillus subtilis) in various doses descriptively known to have an influence on the growth of chili plants which can increase plant height, leaf number, and fruit weight [13]. In the Haryantini research, it was found that the addition of mycorrhizae was able to provide better results on parameters of plant height, leaf area, and canopy dry weight [14]. The application of bacteria-based biofertilizers grew from the groups of Bacillus sp., Pseudomonas sp., Azospirillum sp., and Azotobacter sp. has been proven to be able to spur growth and production of rice and corn in greenhouses and in the field [15]. Microbial as a decomposer microorganism plays a role in creating a good root growth environment by enlarging the absorption area so that nutrients from inorganic fertilizers are as much as $50 \%$ and the contribution of metabolism from rice plants can be used to grow and develop well. Nutrients that have been absorbed by the roots of the rice plant are then used for the development of panicles and seed filling, so that the amount of grain contains more.

An increase in the number of tillers using an organic fertilizer with inorganic fertilizer due to the availability of enough nutrients and can be absorbed quickly for plants, but it cannot be separated from the influence of organic material that has micro-nutrients in helping the process of growth 
and absorption of nutrients in an optimal and effective. Nyanjang reported that a complete and balanced fertilizer affect the growth and yield of rice because it can augment and restore nutrients that have been lost either washed away or carried by the current crop harvest [16].

Riyanti et al. reported that the application of a half dose of NPK fertilizer with the addition of straw could increase the availability of P that is no different with the use of a single dose of NPK fertilizer. It shows that the straw can donate P substantially to the availability of soil nutrients [17]. Herdiyanti et al., report that research the 50\% reduction in the dose of NPK by embedding hay alone or with the addition of organic fertilizers and biological produce the number of tillers and scores leaf color similar to the treatment of $100 \%$ of the dose of NPK ranged between $17-22$ tillers and score leaves 3,82 to 3,92 [18]. According Dobermann and Fairhurst 1 ton of straw containing 5 - $8 \mathrm{~kg} \mathrm{~N} ; 1,6$ to $2 ., 7 \mathrm{~kg} \mathrm{P}_{2} \mathrm{O}_{5} ; 14-20 \mathrm{~kg} \mathrm{~K}_{2} \mathrm{O} ; 0,5-1,0 \mathrm{~kg} \mathrm{~S}$, and $40-70 \mathrm{~kg}$ of Si, so that the immersion treatment of hay around 8 tonnes ha-1 may contribute about $40-64 \mathrm{~kg} \mathrm{~N} \mathrm{ha}^{-1} ; 12,8$ $-21,6 \mathrm{~kg} \mathrm{P}_{2} \mathrm{O}_{5} \mathrm{ha}^{-1}$, and $112-160 \mathrm{~kg} \mathrm{~K}_{2} \mathrm{O} \mathrm{ha}^{-1}$ [19]. Rohcmah and Sugiyanta stated that the combination of organic and inorganic fertilizers in rice by combining the use of organic fertilizer 10 tons/ha and inorganic fertilizer (200 kg urea/ha $+100 \mathrm{~kg} \mathrm{SP}-36 / \mathrm{ha}+100 \mathrm{~kg} \mathrm{KCl} / \mathrm{ha}$ ) were able to increase the effectiveness of agronomic crops of rice compared to just using inorganic fertilizer [20].

The addition of inorganic and organic fertilizers and their combinations give the availability of $\mathrm{P}$ in an equal number to function in the process of flower formation thus affect the life out panicles. Unsure P element in plants can stimulate the formation of flowers this is due to the provision of fertilizer composition helps repair properties of peat so that better availability of nutrients and can be absorbed by plants [21]. Roidah states that the addition of organic matter to the soil a more powerful influence towards improving nature - the nature of the ground, and grain, so that the $\mathrm{P}$ element is required in large quantities and not specifically to increase the nutrients in the soil [22].

Panicle length greatly influence the amount of grain that contains and make an important contribution in reducing the average percentage of empty grain. Increasing the amount of grain as well as the percentage decrease in grain contains hollow affecting an increasing weight of milled dry grain achieved. Bacteria fastening $\mathrm{N}$ given in the biological organic fertilizer is very helpful in donating nitrogen nutrient that is needed by the rice plants to improve plant growth such as filling grain. [23] reported that the length of the panicle is one component that influences the outcome of the results of the rice plant, so the longer panicles potential results obtained tend to be larger than the shorter panicles [23]. 
Table 3. Number of Tillers, Age Out Panicle, Panicle Length and Panicle Density

\begin{tabular}{ccccc}
\hline \multirow{2}{*}{ Treatment } & \multicolumn{4}{c}{ Parameter Observation } \\
\cline { 2 - 5 } & $\begin{array}{c}\text { Number of } \\
\text { puppies }\end{array}$ & $\begin{array}{c}\text { Age Out Malai } \\
\text { (day) }\end{array}$ & $\begin{array}{c}\text { panicle length } \\
\text { (cm) }\end{array}$ & $\begin{array}{c}\text { panicle density } \\
\text { (tassel) }\end{array}$ \\
\hline P0 & $23.50 \mathrm{c}$ & $70.75 \mathrm{a}$ & $23.67 \mathrm{~b}$ & $3.10 \mathrm{~d}$ \\
P1 & $43.25 \mathrm{ab}$ & $66.50 \mathrm{~b}$ & $24.76 \mathrm{ab}$ & $4.65 \mathrm{~b}$ \\
P2 & $47.75 \mathrm{ab}$ & $67.00 \mathrm{~b}$ & $25.95 \mathrm{a}$ & $5.45 \mathrm{a}$ \\
P3 & $33.37 \mathrm{bc}$ & $66.25 \mathrm{~b}$ & $24.62 \mathrm{ab}$ & $3.8 \mathrm{c}$ \\
P4 & $34.37 \mathrm{bc}$ & $66.50 \mathrm{~b}$ & $24.53 \mathrm{ab}$ & $4.05 \mathrm{c}$ \\
P5 & $41.25 \mathrm{ab}$ & $66.15 \mathrm{~b}$ & $25.56 \mathrm{a}$ & $4.09 \mathrm{c}$ \\
P6 & $54.87 \mathrm{a}$ & $67.25 \mathrm{~b}$ & $24.87 \mathrm{ab}$ & $5.09 \mathrm{ab}$ \\
\hline
\end{tabular}

Numbers followed by the same lowercase letters in each treatment was not significantly different according to Duncan's Multiple Range Test at 5\% level. P0 = Without treatment; $\mathrm{P} 1=50 \%$ inorganic fertilizer; $\mathrm{P} 2=100 \%$ inorganic fertilizer; $\mathrm{P} 3=80 \mathrm{~g}$ of rice straw compost; $\mathrm{P} 4=160 \mathrm{~g}$ rice straw litter $+160 \mathrm{ml}$ consortium of microbial $/$ plant; $\mathrm{P} 5=80 \mathrm{~g}$ of rice straw compost $+50 \%$ inorganic fertilizer; $\mathrm{P} 6=160 \mathrm{~g}$ rice straw litter $+160 \mathrm{ml}$ of microbial consortium $+50 \%$ inorganic fertilizer

\subsection{Number of Grain/Panicle}

Number of grain/panicle, the percentage of empty grain and grain weight/plant can be seen in Table 4.

Table 4. Number of Grain/Panicle, the Percentage of Empty Grain and Grain Weight/Plant

\begin{tabular}{|c|c|c|c|c|}
\hline \multirow[b]{2}{*}{ Treatment } & \multicolumn{4}{|c|}{ Parameter Observation } \\
\hline & $\begin{array}{c}\text { Number of grain / } \\
\text { panicle (Grain) }\end{array}$ & $\begin{array}{c}\text { Weight } \\
\text { Grain / plant (g) } \\
\end{array}$ & $\begin{array}{r}\text { Percen } \\
\text { Empty gr } \\
\end{array}$ & $\begin{array}{l}\operatorname{age} \\
\text { in }(\%) \\
\end{array}$ \\
\hline P0 & $74.30 \quad \mathrm{~d}$ & $18.90 \mathrm{~d}$ & 8.63 & $\mathrm{~A}$ \\
\hline P1 & $115.32 \mathrm{~b}$ & $38.52 \mathrm{~b}$ & 5.24 & $\mathrm{Bc}$ \\
\hline P2 & $138.22 \mathrm{a}$ & 56.44 a & 5.11 & $\mathrm{Bc}$ \\
\hline P3 & $84.40 \mathrm{~d}$ & $20.27 \mathrm{~d}$ & 5.39 & $\mathrm{~B}$ \\
\hline P4 & $99.32 \mathrm{c}$ & $28.65 \mathrm{c}$ & 4.22 & $\mathrm{bc}$ \\
\hline P5 & $104.75 \mathrm{bc}$ & $40.02 \mathrm{~b}$ & 4.45 & $\mathrm{bc}$ \\
\hline P6 & $130.57 \quad \mathrm{a}$ & $57.27 \quad \mathrm{a}$ & 3.62 & $\mathrm{C}$ \\
\hline
\end{tabular}

Numbers followed by the same lowercase letters in each treatment was not significantly different according to Duncan's Multiple Range Test at 5\% level. P0 $=$ Without treatment; $\mathrm{P} 1=50 \%$ inorganic fertilizer; $\mathrm{P} 2=100 \%$ inorganic fertilizer; $\mathrm{P} 3=80 \mathrm{~g}$ of rice straw compost; $\mathrm{P} 4=160 \mathrm{~g}$ rice straw litter $+160 \mathrm{ml}$ consortium of microbial $/$ plant; $\mathrm{P} 5=80 \mathrm{~g}$ of rice straw compost $+50 \%$ inorganic fertilizer; $\mathrm{P} 6=160 \mathrm{~g}$ rice straw litter $+160 \mathrm{ml}$ of microbial consortium $+50 \%$ inorganic fertilizer

Table 4 showed that treatment of P2 and P6 produce the number of grains per panicle and grain weight per plant significantly than treatment P1, P3, P4, P5 and P0 (control). High yield number of grains permalai and weight of grain crop treatments P2 and P6 is caused by the amount and availability of $\mathrm{P}$ and $\mathrm{K}$, the results of administering $100 \%$ inorganic according to recommended dosage and treatment fertilizer $160 \mathrm{~g}$ litter rice straw $+160 \mathrm{ml}$ consortium of microbes $+50 \%$ inorganic thus availability of $\mathrm{P}$ and $\mathrm{K}$ are sufficient for generative growth increase the number of grains per panicle and grain weight because of $\mathrm{P}$ and $\mathrm{K}$ is essential for seed formation. Eka research results and Nasir report that the highest yields number of filled grain per panicle varieties produce situ bagendit 138.63 grains per panicle. Differences in grain yield per panicle is caused 
by organic and inorganic fertilizer application that is able to meet the availability of nutrients that plants need good administration before planting and at the age of 14 days after planting [24]. Primanto stated that the generative phase of the plants need a lot of nutrients to produce energy for the plant, namely phosphorus (P) and potassium (K) [25].

NPK dose reduction of $50 \%$ with the addition of $160 \mathrm{~g}$ of rice straw litter $+160 \mathrm{ml}$ of microbial consortium produces more number of grains per panicle and grain weight per plant which is equal to $100 \%$ of the dose of NPK treatment. Rice straw has been buried and the addition of microbial consortium was decomposed carefully so that it can provide the necessary nutrients of rice plants. According Sidu and Beri, decomposition of organic matter by soil microorganisms are removing the role of N, P, K, Mg, S, and Si [26]. Saha et al. adding that the application of organic manure with inorganic fertilizer but can save the use of organic fertilizer, to prevent an imbalance of nutrients, improve soil fertility and increase rice yields [27]. The research result Puspitawati et al. showed that the use of microbial solvents $\mathrm{P}$ can reduce the use of inorganic $\mathrm{P}$ by $50 \%$ and can increase grain yield and P uptake in straw and grain [28]. The use of biological fertilizers containing Azotobacter bacteria consortium and Azosprillum can reduce the 25\% usage of inorganic nitrogen fertilizers doses of recommendation $\left(100 \mathrm{~kg} \mathrm{ha}^{-1}\right)$ without lowering the yield [29]. According Fadiluddin, upland rice crop fertilizer combination of biological, inorganic and organic can improve nutrient uptake total of up to $99,40 \%$ and $80,60 \%$, increasing the number of filled grain per panicle up to $76.00 \%$ and $76.10 \%$ and grain weight contents per clump up to 51.50 and $63.70 \%$ compared to controls [30].

\subsection{Nutrient Content of Peat After Harvest}

Based on the results of the research, the results of the measurement of the total $\mathrm{N}$ of peat soil after the research resulted in values ranging between $0.34-0.56 \%$. Where according Hardjowigeno classifying that the total value of $\mathrm{N}$ in peat soil the rest of the study was classified as moderate. This is because Nitrogen in the soil is bound by clay minerals in shape $\mathrm{NH}^{4+}$. Loss of $\mathrm{N}$ from the soil can be caused by several things, which are used by plants or microorganisms, washing, bound by clay minerals and denitrification process [31]. Baon et al., states that $\mathrm{N}$ loss in soil is caused by $\mathrm{N}$ being converted to $\mathrm{NH}^{4+}$ by being absorbed by adsorbing $\mathrm{NH}^{4+}$ so that ammonium is difficult to change to $\mathrm{N}^{3-}$, the adsorbed ammonium will be released slowly through cation exchange [32]. Winarso, states that organic $\mathrm{N}$ levels added to peat soil cause a decrease in inorganic $\mathrm{N}$, when compared to soil without the addition of organic matter. There are three main forms of $\mathrm{N}$ in the soil ( $\mathrm{N}$-organic, $\mathrm{NH}^{4+}, \mathrm{NO}^{3-}$ ), Ion $\mathrm{NH}^{4+}$ more stable in the ground compared to $\mathrm{NO}^{3-}$ because it can be tied in the treads both in organic and inorganic clay so that $\mathrm{NH}^{4+}$ kept in the ground [33].

According Hardjowigeno value P Available on peat soil after the research is very high. P2 treatment (100\% organic) produce $1668.00 \mathrm{ppm}$ are very high compared to the rest of the soil nutrient in the treatment P3 $684.00 \mathrm{ppm}$. Darman, adding that the organic compounds derived from plant residues containing elements $\mathrm{P}$, so that when administered into the soil will increase $\mathrm{P}$ 
in the soil [34]. Availability of $\mathrm{P}$ in the soil by $\mathrm{pH}$, ion $\mathrm{Fe}, \mathrm{Al}$, and the rate of decomposition of organic matter. Incubated compost soil $\mathrm{pH}$ increased, as the increase in $\mathrm{pH}$ so the content of Al$\mathrm{P}$ and Fe-P can break off and become a form provided for peat [35]. Compost that also serves as an organic material, can increase the availability of $P$.

Table 5. Nutrient Content of Peat after Harvest

\begin{tabular}{ccccccc}
\hline \multirow{2}{*}{ Treatment } & \multicolumn{5}{c}{ Nutrient Content of Peat } \\
\cline { 2 - 6 } & N total (\%) & $\begin{array}{c}\text { P Available } \\
\text { (ppm) }\end{array}$ & K total (\%) \\
\hline P1 & 0,35 & b & 1060,50 & c & 1,04 & a \\
P2 & 0,36 & b & 1668,00 & a & 1,17 & a \\
P3 & 0,56 & a & 684,00 & d & 1,17 & a \\
P4 & 0,48 & ab & 1389,00 & b & 1,06 & a \\
P5 & 0,38 & b & 1319,50 & b & 0,92 & a \\
P6 & 0,34 & b & 1450,50 & b & 1,14 & a \\
\hline
\end{tabular}

Figures followed by the same lowercase letters in each treatment was not significantly different according to Duncan Multiple at 5\% level. P1 $=50 \%$ Inorganic according to recommended dosage; $\mathrm{P} 2=100 \%$ inorganic according to recommended dosage; $\mathrm{P} 3=80$ $\mathrm{g}$ of rice straw compost; $\mathrm{P} 4=160 \mathrm{~g}$ rice straw litter $+160 \mathrm{ml}$ consortium of microbial / plant; $\mathrm{P} 5=80 \mathrm{~g}$ of rice straw compost $+50 \%$ inorganic; $\mathrm{P} 6=160 \mathrm{~g}$ rice straw litter +160 $\mathrm{ml}$ of microbial consortium $+50 \%$ inorganic

Based on the results of measurements of the $\mathrm{K}$ total research peat after investigation resulted in values ranging from 0.92 to $1.17 \%$. Improved $\mathrm{K}$ of the addition is because the source of potassium ameliorant brought by organic matter in organic matter litter rice straw and rice straw compost with the addition of microbes that help overhaul and repair of soil biology. This is because the amount of cations base such as $\mathrm{K}^{+}, \mathrm{Mg}^{2+}, \mathrm{Ca}^{2+}$ and $\mathrm{Na}^{+}$were donated has been absorbed and dominated the complex sorption, an indication that the cations bases have been entrapped and more on colloid ground compared with $\mathrm{Al}^{3+}$ and $\mathrm{H}^{+}[36]$.

\section{Conclusions and Recommendation}

Organic fertilizers and inorganic fertilizers as well as the addition of microbial significantly enhances growth and yield of rice on peat. The addition of rice straw litter $160 \mathrm{~g}+160 \mathrm{ml}$ of microbial selulolitic consortium $+50 \%$ inorganic fertilizer is best treated by producing the number of grains per panicle achieve weighing 130,57 grains of grain crops reached 150,08 grams, with a percentage of $3,62 \%$ which is the lowest empty. The addition of rice straw litter $160 \mathrm{~g}+160 \mathrm{ml}$ of microbial selulolitic consortium $+50 \%$ inorganic fertilizer and microb selulolitic consortium inorganic showed similar results with an increase of $100 \%$ inorganic fertilizer thus of rice straw litter $160 \mathrm{~g}+160 \mathrm{ml}$ of microbial selulolitic consortium $+50 \%$ inorganic fertilizer treatment can reduce the use of inorganic fertilizers as much as $50 \%$ inorganic fertilizer. This research was conducted on peat media, for the next researchers suggested to be able to conduct research on a field scale. 


\section{Acknowledgments}

Thanks to the Ministry of Research and Technology (KEMENRISTEKDIKTI) through the financial support Fundamental Research Grants Fiscal Year (2018), chaired by Prof. Dr. Ir. Hapsoh, MS.

\section{REFERENCES}

[1] D. Riniarsi, "Outlook komoditas pertanian tanaman pangan kedelai," Jakarta: Pusat Data dan Sistem Informasi Pertanian Kementerian Pertanian, 2015.

[1] A. Sulaiman, N. N. S. Eli, and S. Asmadi, "Panduan teknis pemantauan tinggi muka air lahan gambut sistem telemetri”, Badan Restorasi Gambut Republik Indonesia, pp. 58, 2017.

[2] S. Rahutomo and Winarna, "Restorasi gambut dan tinjauan terhadap PP No. 57 Tahun 2016 PPKS", Note April 2017, Pusat Penelitian Kelapa Sawit, pp. 1, 2017.

[3] Tim Sintesis Kebijakan, "Pemanfaatan dan konservasi ekosistem lahan rawa gambut di Kalimantan", Balai Besar Penelitian dan Pengembangan Sumber Daya Lahan Pertanian, Jurnal Pengembangan Inovasi Pertanian, vol. 1, no. 2, pp. 149-156, 2008.

[4] A. S. Rosmimi, "Serapan hara N, P, K dan pertumbuhan tanaman padi (Oryza sativa L.) di medium gambut yang diaplikasikan amelioran dregs dan pupuk N, P, K," Jurnal Agrotek. Trop, vol. 1, no. 2, pp. 21-30, 2012

[5] B. Sufardi, and Bakhtiar, "Serapan hara dan efisiensi pemupukan phosfat serta pertumbuhan padi varietas lokal”, Jurnal Manajemen Sumberdaya Lahan, vol. 1, no. 2, pp. 159-160, 2012.

[6] I. Ekawati, "Pengaruh pemberian inokulum terhadap kecepatan pengomposan jerami padi", Jurnal Penelitian Pertanian, vol. 11, no. 2, 2003.

[7] R, Saraswati and Sumarno, "Pemanfaatan mikroba penyubur tanah sebagai komponen teknologi pertanian" Bogor, 2008.

[8] A. S. Baharuddin et al., "Isolasi and characterization of thermophilic cellulase-producing bacteria from empty bunches-palm oil mill effluent compost", Journal of Applied Science, vol. 7, no. 1, pp. 56-62, 2010.

[9] Riswandi, "Kajian stabilitas gambut tropika indonesia berdasarkan analisis kalangan karbon organik sifat fisik, kimia dan komposisi bahan gambut", Disertasi, Program Pascasarjana Institut Pertanian Bogor, 2001.

[10] B. Radjagukguk, "Perspektif permasalahan dan konsepsi pengelolaan lahan gambut tropika untuk pertanian berkelanjutan", Pidato Pengukuhan Jabatan Guru Besar pada Fakultas Pertanian Universitas Gadjah Mada, Yogyakarta, 2001.

[11] F. Agus and I. G. Subiksa, "Lahan gambut: potensi untuk pertanian dan aspek lingkungan", Balai Penelitian Tanah, Bogor, pp. 6, 2008.

[12] T. Yuwono, "Kecepatan dekomposisi dan kualitas kompos sampah organik", Jurnal Inovasi Pertanian, vol. 4, 2007.

[13] F. K. Supriyanto, Umah, and T. Surtiningsih, "Pengaruh pemberian pupuk hayati (biofertilizer) dan media tanam yang berbeda pada pertumbuhan dan produktivitas tanaman cabai rawit (Capsicumfrutescens L.) di Polibag", Skripsi, Departemen Biologi Fakultas Sains dan Teknologi, Universitas Airlangga, Surabaya, 2011.

[14] B. A. Haryantini and M. Santoso, "Pertumbuhan dan Hasil Cabai Merah pada Andisol yang diberi Mikoriza, Pupuk Fosfor dan Zat Pengatur Tumbuh”, Biosain, vol. 1, pp. 50-57, 2001.

[15] Hamim, N. R. Mubarik, I. Hanarida, and N. Sumarni, "Pengaruh pupuk hayati terhadap pola serapan hara, ketahanan penyakit, produksi, dan kualitas hasil beberapa komoditas tanaman pangan dan sayuran unggulan", Laporan penelitian KKP3T, Institut Pertanian Bogor, Bogor, 2008. 
[16] R. Nyanjang, A. A. Salim, and Y. Rahmiati, "Penggunaan pupuk majemuk NPK 25-7-7 terhadap peningkatan produksi mutu pada tanaman teh menghasilkan di tanah andisols di PT. Perkebunan Nusantara XII”, Prosiding Seminar, 2003.

[17] S. Riyanti, H. Purnamawati, and Sugiyanta, "Pengaruh aplikasi pupuk organik dan pupuk hayati serta reduksi pupuk NPK terhadap ketersediaan hara dan populasi mikroba tanah pada tanaman padi sawah musim tanam kedua di Karawang, Jawa Barat", Bulletin Agrohorti, vol. 3, no. 3, pp. 330-339, 2015.

[18] T. Herdiyati, Sugiyanta, and A. Hajrial, "Tanggap tiga varietas padi sawah terhadap kombinasi pemupukan dengan sistem pembenaman jerami", Jurnal Agron Indonesia, vol. 43, no. 3, pp. 179-185, 2015.

[19] A. Dobermann and T. H. Fairhurst, Rice straw management, Better Crop International 16, pp.7-11, 2002.

[20] H. F. Rohmah and Sugiyanta, "Pengaruh pupuk organik dan organik terhadap pertumbuhan padi sawah", Makalah Seminar Departemen Agronomi dan Hortikultura IPB, Bogor, 2010.

[21] M. Sutedjo, Pupuk dan Cara Pemupukan. Jakarta: Rineka Cipta, 2002.

[22] I. S. Roidah, "Manfaat penggunaan pupuk organik untuk kesuburan tanah", BONOROWO, vol. 1, no. 1, 2013.

[23] A. Kustera, "Keragaman Genotipe dan Fenotipe Galur-Galur Padi Hibrida Di Desa Kahuman, Polanharjo Klaten," Skripsi. Jurusan/Program Studi Agronomi. Fakultas Pertanian. Universitas Sebelas Maret. Surakarta, 2008.

[24] F. M. Eka, and A, Nasir, "Kelayakan Usaha Tani Padi Gogo Dengan Pola Pengelolaan Tanaman Terpadu (PTT) Di Kabupaten Aceh Besar, Provinsi Aceh", Widyariset, Vol. 17 (3), pp.425-434, 2014.

[25] H. Primanto, Pemupukan Tanaman Buah. Jakarta, Penebar Swadaya, pp. 73, 1998.

[26] B. S. Sidhu and V. Beri, "Rice residue management: farmer's perspective", Indian Jurnal Air Pollution Control, vol. 8, pp.61-67, 2008.

[27] R. Saha, M. A. U. Saieed, and M. A. K. Chowdhury. "Growth and yield of rice (Oryza sativa) as influenced by humic acid and poultry manure", Universal Journal. Plant Sci., vol. 1, pp. 78-84, 2013.

[28] M.D. Puspitawati, Sugiyanta, and I. Anas, "Pemanfaatan mikrob pelarut fosfat untuk mengurangi dosis pupuk P anorganik pada padi sawah", Jurnal Agron Indonesia, vol. 41, pp. 188-195, 2013.

[29] I. Widiyawati, A. Sugiyanta, R. Junaedi, and Widyastuti, "Peran bakteri penambat nitrogen untuk mengurangi dosis pupuk nitogen anorganik pada padi sawah", Jurnal Agron Indonesia, vol. 42, pp. 96-102, 2014.

[30] M. Fadiluddin, "Efektivitas Formula Pupuk Hayati dalam Memacu Serapan Hara, Produksi dan Kualitas Hasil Jagung dan Padi Gogo di Lapang", Tesis. Sekolah Pasca Sarjana, Institut Pertanian Bogor, Bogor, 2009.

[31] S. Hardjowigeno, Ilmu Tanah, Jakarta: Akademika Pressindo, 268, 2003.

[32] J. B. Baon, F. Inayah, B. Suhartono, and S. Winarso, "Efisiensi pemupukan nitrogen, sifat kimiawi tanah dan pertumbuhan kakao akibat dosis dan ukuran zeolit", Jurnal Perkebunan, vol. 19, no. 3, pp. 126-139, 2003.

[33] S. Winarso, Kesuburan Tanah: Dasar Kesehatan dan Kualitas Tanah, Yogjakarta: Gava Media, pp. 269, 2005.

[34] S. Darman, "Ketersediaan dan serapan hara $\mathrm{P}$ tanaman jagung manis pada Oxid Dystrudephisb Palolo akibat pemberian ekstrak kompos buah kakao", Jurnal Agroland, vol. 15, no. 4, pp. 323-329, 2008.

[35] R. Susanto, Dasar-Dasar Ilmu Tanah. Jakarta: Kanisius, pp. 67, 2005. 
[36] I. A. Mahbub, A. Muzar, and Ermadani, "Pengaruh residu kompos tandan buah kelapa sawit terhadap beberapa sifat kimia ultisol dan hasil kedelai", Jurnal Penelitian Universitas Jambi Seri Sains, vol. 13, no. 2, pp.11-18, 2011. 